\title{
DIDACTICS
}

๙

\author{
Krystian Kamiński \\ Maria Curie-SkŁodowska University in Lublin \\ KRYS.KAMI@GMAIL.COM \\ HTTPS://ORCID.ORG/OOOO-0OO1-6826-8052
}

\section{Very Young Learners in a Gallery of Modern Art - Possible Opportunities Arising from the Implementation of Modern Art in Foreign Language Teaching}

\begin{abstract}
Inviting very young learners to a gallery of modern art does not seem as an obvious didactic solution. Some may argue that children are not able to interpret modern art, and, therefore, it is not possible to use such a medium as a teaching tool. However, it all depends on the pedagogical approach and the way art is implemented during classes.

This article starts with an overview of definitions of very young learners, defining this group not only in terms of their age, but also characteristic traits. It is also to justify the use of modern art-cued visual materials as a component of language teaching and to ponder upon using elements of artistic creation to foreign language classrooms. The practical implementation of a presented solution is also discussed in the article. The ideas were used as workshops aimed at introducing very young learners to modern art as well as at acquiring new English vocabulary. Classes were carried out in one of the modern art galleries in Lublin. An example of chosen artwork and pieces created by a very young learner are shown in this article. Finally, the opportunities arising from implementing the new methodology are analysed. They are connected with linguistic development, improvement of young learners' skills, as well as developing intercultural competence.
\end{abstract}

Keywords: modern visual arts, very young learners, teaching very young learners, teaching vocabulary, intercultural competence, visuals in language teaching 


\section{Introduction}

The question whether children should begin foreign language learning at an early age has been raised by various researchers in the last decade (Sobańska-Jędrych, Karpeta-Peć, and Torenc 2013; Kic-Drgas 2014; Kotarba-Kańczugowska 2015). What the latest research shows is that teaching foreign languages to very young children may have a positive impact on their future level of language proficiency (Kic-Drgas 2014, 92). Therefore, both researchers and teachers are looking for new didactic methods and more creative ways of introducing a foreign language to this group of learners that is still growing.

One of the ways of making foreign language learning more effective is revising already known traditional techniques and teaching aids. Researchers try to use them in new contexts, seek unusual forms, experiment and make attempts to get the most of them. The implementation of modern artwork as visual aids is an example of such an approach. It is providing a fresh new face to existing solutions and seems to be appealing because of a plethora of forms presented by modern art (paintings, prints, lightboxes, tactile diagrams, installations, performances, videoworks, site-specific art).

The world in the twenty-first century seems to be a global village full of various ideas and perspectives. All these concepts can be found in contemporary art which is used by artists as one of the ways of exploring and understanding reality. A variety of artistic forms of expression as well as internationality and diversity of modern art can provide a basis for learning languages since this process requires developing the ability to understand the foreign. As already mentioned, contemporary art provides a wide range of artistic forms that can be used as uncommon visual aids. The impact of implementation of visual aids during language classes is self-evident (Grant 1991; Sochaczewska-Kuleta 2000a; Hill 2004). The combination of these two factors is the main point of the idea presented in this article.

The main aim of this article is to present the possibility of introducing modern art as a valuable teaching aid and examine opportunities arising from the implementation of this tool for language learning. Debated issues concern providing characteristic traits of a chosen group of learners - very young children. This article also ponders upon potential use of modern art-cued visual aids in various forms. Finally, it shows possible practical implementation of aforementioned issues in the form of workshops for very young learners.

The suggestions were created on the basis of theoretical discussion as presented in, among others, Scott and Ytreberg (1990), Wright and Haleem (1991), Iluk (2002), Kic-Drgas (2014), Bonner and Reinders (2018). 
Very Young Learners in a Gallery of Modern Art - Possible Opportunities Arising... 65

\section{Very Young Learners}

Various researchers present different definitions of a very young learner (Scott and Ytreberg 1990; Brewster, Ellis, and Girard [1992] 2002; Reilly and Ward [1997] 2003; Cameron [2001] 2003; Kic-Drgas 2014). Scott and Ytreberg (1990, 1) as well as Cameron ([2001] 2003, XI) share the opinion that very young learners are children between five and twelve years of age. This approach considers very young learners only in the context of mandatory education. However, Reilly and Ward ([1997] 2003,3) claim that the "term 'very young learners' refers to children who have not yet started compulsory schooling and have not yet started to read". In various countries the age when children begin compulsory schooling may be different, even up to the age of seven. So, the realistic average age of a very young learner should be stated as three to six years old (Reilly and Ward [1997] 2003, 3).

Some researchers go even further and nurture a more flexible approach. According to Brewster, Ellis and Girard ([1992] 2002, 1), nowadays there is a widespread belief that the younger a child starts learning a foreign language, the better. Therefore, no minimum age for very young learners should be determined. Kic-Drgas $(2014,93)$ expands this view, diversifying five groups of very young learners on the basis of their needs as language learners as follows:

- 2-3 years of age,

- early childhood stage (3-4 years of age),

- preschool stage (4-5 years of age),

- preschool-school stage (6 years of age),

- primary education stage (6/7-10 years of age).

Taking into consideration presented definitions and approaches it can be stated that "very young learners" is a catch-all term for students who are not yet adults. It swept into fashion reflecting the trend to lower the starting age and broaden access to English language learning to younger people in many countries all over the world. Since this term may be interpreted in different ways, for the purpose of this experiment, the target group was narrowed down and focus was put mainly on children between 3 and 6 years old.

According to Ellis (1991) and Cameron ([2001] 2003), the most important factors for language learners are age, aptitude, motivation and personality. Therefore, taking into account age only is not sufficient to create the most accurate description of very young learners. Since "it is not possible to say that at the age of five all children can do $\mathrm{x}$, at the age of seven they can all do $\mathrm{y}$, or that at the age of ten they can all do z" (Scott and Ytreberg, 1990, 1), one should consider various individual features of children at all stages of development as well.

It is impossible to make a detailed description of how very young children learn languages. Each learner is different and should be treated individually. However, making a list of general characteristics of this group is possible (Kic-Drgas 2014, 93) and may be valuable for teachers who should be aware of certain features. It is advisable 
to take them into consideration while preparing lesson plans for very young learners (Scott and Ytreberg 1990, 5).

One of the most important characteristics of very young children is that they do not focus on learning itself. In their case, learning happens "by the way" while they are involved in other activities that include educational elements (Kic-Drgas 2014, 94). Therefore, various kinds of games and plays are the best for this age group. Very young learners do not have intrinsic motivation (Pamuła 2004) and do not learn in a conscious way (Kic-Drgas 2014, 94). That is why games should involve children's attention and entertain them. Iluk $(2002,65)$ claims that important purposes of games and plays are also to activate imagination and to develop motor skills.

Physical activity is used by very young learners to discover reality around them. It is very important for children at this stage to move, therefore they express themselves more frequently through action than through words (Kotarba-Kańczugowska 2015, 46). Very young learners have difficulties focusing on a single activity for a long time. They are curious about the world around them (Scott, Ytreberg 1990). Iluk $(2002,76)$ claims that an important part of language instruction for very young learners should be numerous tasks that require any kind of physical activity.

Because very young learners memorise new knowledge more effectively in a friendly environment (Pamuła 2004), lessons for this group of children should be planned to provide the best possible atmosphere for learning, therefore children should feel appreciated and needed. In the case of very young learners, learning itself may take the form of language play. So, it is advisable to implement games as a part of language activities to make learners feel happy and motivate them to participate actively in classes (Iluk 2002, 66). It should be possible for children to actively participate in all activities, therefore singing songs, making up rhymes, experimenting with words and sounds should be included in lesson plans for very young learners (Scott Ytreberg 1990). Jaroszewska (2008) claims that children should have a feeling of achievement, therefore the most important aspect in teaching very young learners are not measurable effects, but activities that are undertaken during classes (Komorowska 2005, 29).

\section{Modern Art-Cued Visual Aids}

The possibilities of implementation of visual aids in language teaching are almost unlimited. Teachers can use them to increase the level of learners' involvement and to raise their interest in learning a foreign language (Sochaczewska-Kuleta 2000b, 80). Some may claim that visual aids are only suitable for visual learners because this group thinks in images and memorises new knowledge better with the use of pictures (Gilakjani 2012, 105). However, by using different kinds of visuals to the fullest, new and powerful approaches in language classrooms can be developed. Such approaches appear to be useful for all types of learners - visual, auditory, and kinaesthetic (Gilakjani 2012, 105-106). Moreover, visual aids should be implemented in the case of very 
Very Young Learners in a Gallery of Modern Art - Possible Opportunities Arising... 67

young language learners as frequently as possible, because children at this age do not have the ability of abstract thinking and need numerous stimuli in order to capture their attention (Komorowska 2005, 32).

A plethora of types and kinds of visual aids makes them one of the most useful resources in language classrooms (Wright and Haleem 1991, 3). A list of various visual aids presented below includes some basic ones that can be found in almost every school as well as advanced tools used in modern schooling systems (Wright [1989] 1990; Wright and Haleem 1991; Hill 2004, 297; Barber, Cooper, and Meeson 2008; Havé 2013, 14; Bonner and Reinders 2018, 33). Researchers agree that implementation of visual aids of any kind has a positive influence on the process of learning (Grant 1991; Hill 2004, 297).

Table 1. Examples of visual aids

\begin{tabular}{l|l}
\hline Most common visual aids: & More advanced visual aids: \\
\hline - pictures, collages, wall posters, & - interactive whiteboards, \\
- worksheets, & - touchscreens, \\
- chalkboards, whiteboards, magnetboards, & - mobile phones, \\
- flashcards with pictures and words, & - tablets, \\
- magazine illustrations, & - internet, \\
- videos, & - YouTube, \\
- visuals on overhead projectors. & - augmented and virtual reality. \\
\hline
\end{tabular}

Kic-Drgas $(2014,94)$ provides examples of activities that are most desired by very young learners. They are, among others, artistic and creative tasks concerning creating crafts and artistic works by learners. Pamuła (2004) claims that such exercises as drawing, cutting, colouring, painting and sketching can contribute to introducing a friendly atmosphere during classes. They develop the creativity of children, involve children's attention, and are simply amusing. Therefore, artistic creation can be seen as an important part of the comprehensive education process and shall be used as a regular teaching aid (Art as a Tool for Teachers of English Language Learners 2010).

Sochaczewska-Kuleta $(2000 \mathrm{~b}, 80)$ and Havé $(2013,15)$ share the view that works of modern art can be used as visual aids of numerous forms and various implementation possibilities. More traditional visual aids in language teaching can be successfully supplemented or even substituted by works of art (Havé 2013, 15). Modern art encompasses a wide variety of artistic forms, among others: painting, installation, artistic objects, video art, performance, and therefore, it can be implemented as a resource of visual aids. As it is shown by Sochaczewska-Kuleta (2000a), new methods and unusual materials in language teaching can and should be implemented since they have a positive impact on the process of learning. That is why practical solutions that are to be presented later are using the idea of modern art-cued visual aids. 


\section{Practical Implementation}

Theoretical discussions presented in previous parts of this article led to proposing a new way of teaching language aimed at introducing very young learners to modern art as well as acquiring new English vocabulary. The solutions have been implemented as workshops for children between 3 and 6 years of age, as a part of Galeria Labirynt modern art gallery in the Lublin education programme - from September 2017 to August 2019. The workshop was available to everyone who had signed up for the class. The total number of participants in the entire series of classes was 120 children. The only selection criterion was the age of the participants. The organizers cared about the diversity of children participating in the workshops, therefore they were children from different backgrounds, with different levels of language knowledge and with different access to culture. Some of the participants were present at more than one meeting in the series.

Creating workshops based on including modern art in language teaching was both a challenging and difficult task. Various factors had to be taken into account - among others, the language level of learners and their perception abilities, the extent to which children can understand art and the choice of themes to be presented. Some possible problems and pitfalls arising from the nature of exercises and other external factors were also considered. In order to facilitate appropriate learning conditions for very young learners, characteristic features of this group had to be matched with possible use of modern artworks. It was decided that each workshop should consist of two parts:

1. teaching vocabulary with the use of modern art,

2. creating a piece of art by learners based on modern artworks presented before.

The focus of the first phase was to illustrate different ways in which modern art can be used to introduce new vocabulary items to very young learners. The most difficult task during this stage turned out to be selecting appropriate works of modern art. Chosen artworks had to be appropriate for very young learners and suitable for teaching purposes. This means that pieces of art had to be simple to understand for children and could not carry violent, offensive or too formal and deep meanings. What is more, they had to include such elements that would enable the teacher to present selected vocabulary items and create successful activities. Most artwork chosen for purposes of the workshops can be found on the internet. Some of them are in the collection of Galeria Labirynt modern art gallery in Lublin.

The process of development was carried out in close cooperation with employees of the education department of Galeria Labirynt in Lublin. The first step was collecting works from the collection of the institution, which, according to educators, were suitable for use during workshops with a selected group of participants. Then, the works were grouped in terms of subject matter, elements presented visually and used means of artistic expression. The works selected according to the mentioned criteria were then an inspiration and a starting point for artistic activities undertaken during the workshops. The presented vocabulary items included such topics as: colours, seasons, Christmas, numbers, elephants, senses, shapes. 
Each meeting included a part when learners created their own piece of art based on modern artwork(s) presented by the teacher. One of the most crucial points here was to use uncommon ways to prepare the pieces of art. This means choosing such materials and techniques that are not usual for art classes - painting with everything else but brushes, for example, with half-cooked noodles, toothbrushes, kitchen utensils or clothes pegs and knitting wool; making edible paint, creating tactile diagrams, implementing sensory plays, large-scale painting, torn paper collages, and so on.

The combination of foreign language vocabulary and creative activity was an important element of the presented idea. Fulfilling the need for creative expression (Komorowska 2005) is closely related to child development (Pamuła 2004) and the way very young students express their feelings. Therefore, when teaching the language during the workshops, it was important to implement creative activities based on modern art. Kic-Drgas $(2014,94)$ emphasises that various forms of artistic activity are a stimulus that helps develop speaking skills and supports language learning as a whole. Language development occurs along with emotional development. Komorowska (2005) also underlines the need to combine children's educational activities with such activities as drawing, colouring and cutting. That is why art-based activities focused on developing learners' creativity and curiosity, contributing to the development of language learning in very young learners, were an important feature of each of the workshops.

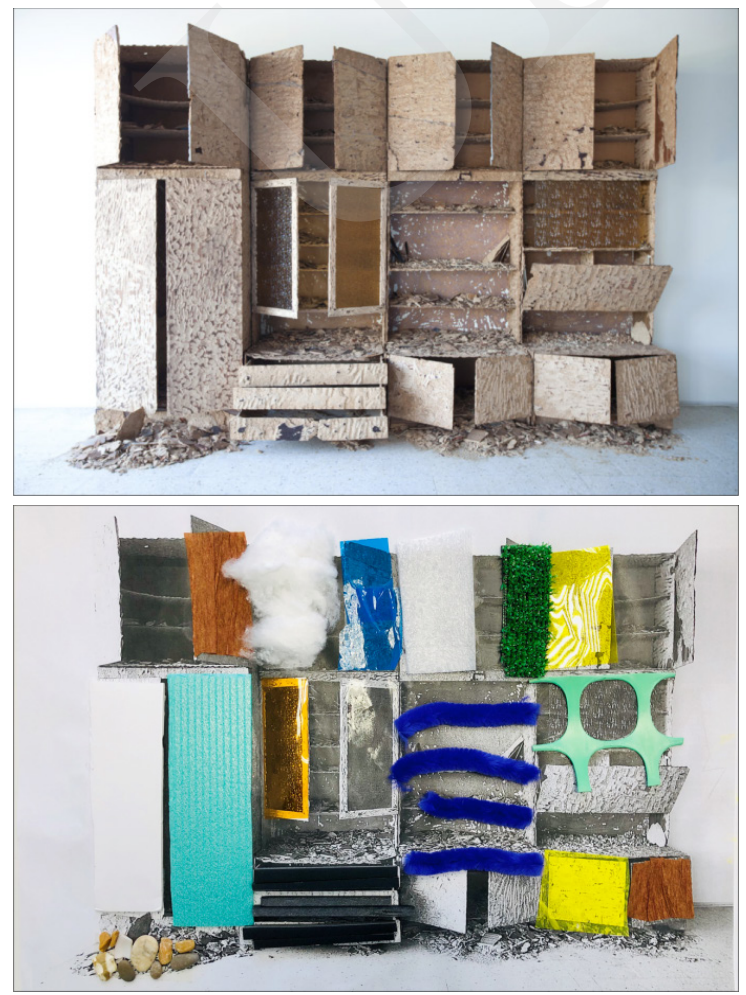

Photo 1.

Roman Stańczak - "Meblościanka" (1996)

glass, wood, Museum of Modern

Art, Warsaw, Poland

photo credit Wojciech Pacewicz

Photo 2.

work of art created by a very

young learner during workshop

inspired by Roman Stańczak's work

"Meblościanka"

photo credit Krystian Kamiński 


\section{Opportunities arising from the use of modern art in foreign language teaching}

The presented way of language teaching is supposed to bring language learners advantages. Therefore, opportunities arising from the implementation of modern visual arts as a teaching tool shall be examined. Theoretical discussions as well as carried workshops suggest the following possible benefits are seen to be the most valuable for workshop participants:

- acquiring new English vocabulary,

- improving fine motor skills,

- expanding creativity and imagination,

- developing intercultural competence.

Acquiring new vocabulary is regarded as one of the possible results of the presented idea. The workshop included such elements as physical activity and various language games and plays in order to make learning as beneficial for learners as possible. It was important to create by using activities and to introduce a friendly atmosphere of meetings. All levels of exercises connected with art, such as painting, drawing, cutting, gluing, and colouring were adapted to the abilities of very young learners. The main focus in this area was on designing activities that would be neither too easy nor too difficult for children. It was also important to work on improving fine motor skills and visual discrimination of workshop participants. Those two abilities are thought to be developed through activities concerning cutting, colouring, tracing, and pasting (Sherrill 2010,3). Parts of workshops when learners were creating their own works of art contributed to expanding their creativity and imagination. Activities that allow children to create freely, with almost no limitations are the best way to reinforce their creative skills (Komorowska 2005, 32). Moreover, such tasks help to build their interest in what is happening during classes (Pamuła 2004).

Another opportunity, thus a possible result of implanted activities, arising from the implementation of modern art in foreign language teaching could be developing intercultural competence. This notion is defined as the ability to understand non-verbal as well as verbal culture-based signals (Tomalin and Stempleski 1993). Myczko (2005, 29) claims that intercultural competence facilitates communication of speakers not only within different cultures but also between them. Pawłowska $(2010,60)$ emphasises that intercultural competence means being aware of culture-based differences and being able to face new unknown culture-specific situations resulting from mentioned differences. By interacting with modern works of art during workshops, intercultural competence could be developed. It is seen as a possible outcome of meeting an entirely new and unknown reality created by modern artists of various foreign origins. The learner's knowledge of his/her native language is in such a case used to explore that new reality. It is possible that such a confrontation prepares a learner for cooperation with members of foreign communities and develops attitudes of open-mindedness, tolerance, and acceptance. 


\section{Conclusions}

The idea of implementing modern visual art was a result of profound theoretical exploration of the subject. The main point of teaching language was to create exercises for very young learners and to prove that modern visual art can be successfully used as a teaching aid for language learning. The developed idea has been implemented into workshops at the Galeria Labirynt modern art gallery in Lublin. In the course of the development of the programme, certain opportunities that could have resulted from its implementation have been proposed. The teachers who nowadays want to find some interesting methods as well as new creative ways of teaching languages should acknowledge the potential and value of these practical solutions and give them methodological credit.

The constantly changing reality of the 21 st century poses new challenges both to language teachers and to language learners. The teachers have to face the growing number of very young learners and develop the most appropriate didactic tools for this age group. The role of contemporary educators is also preparing learners to function in diverse and multicultural contexts. Therefore, learners should be equipped with knowledge about the world as well as skills and attitudes appropriate for functioning in modern societies. A kind of knowledge that facilitates openness and understanding toward a foreign culture is intercultural competence. One of the aids that can be implemented for teaching intercultural competence is modern art - an international and diverse concept. Approaches to perception of modern art vary. Some say that an artwork carries simply a visual message. On the other hand, it can tell the audience something about the artists and about society in general (Have 2013, 15). So, art seems to be a good element to show similarities and differences between countries and, therefore, to initiate understanding of foreign cultures and foreign people.

Some other possible opportunities arising from the implementation of modern art in teaching very young learners appears to be development of creativity and imagination. This is presumed as the effect of learners being exposed to artwork of numerous artistic movements created with the use of various techniques. Learners created their own creative artwork inspired by examples presented by the teacher. They were free to express themselves and to create with the use of unusual means. It is also believed that the workshops contributed to improving the fine motor skills of learners through implementing activities including manual exercises tailored for the level of abilities of very young learners.

\section{References}

Barber, David, Linda Cooper, and Graham Meeson. 2008. Learning and Teaching with Interactive Whiteboards. Primary and Early Years. Exeter: Learning Matters Ltd.

Bonner, Euan, and Reinders Hayo. 2018. "Augmented and Virtual Reality in the Language Classroom: Practical Ideas”. Teaching English with Technology 18(3): 33-53. 
Brewster, Jean, Gail Ellis, and Denis Girard. (1992) 2003. The Primary English Teacher's Guide. Reprint, Harlow: Penguin English.

Cameron, Lynne. (2001) 2003. Teaching Languages to Young Learners. Reprint, New York: Cambridge University Press.

Gilakjani, Pourhosein. 2012. "Visual, auditory, kinaesthetic learning styles and their impact on English Language Teaching”. Journal of Studies in Education 2(1): 104-113.

Grant, Neville. 1991. "Preface". In Visuals for the Language Classroom, eds. Andrew Wright, and Safia Haleem. New York: Longman.

Havé, Philippe. 2013. The use of art in English language teaching: Developing learners' receptive and productive skills by engaging with masterpieces from classical to modern art. https://portal.education.lu/inno/PROJETS/Projets-Détail/ArtMID/3328/ArticleID/7244

Hill, David A. 2004. "Visual aids". In Routledge Encyclopedia of Language Teaching and Learning, ed. Michael Byram. 297-300. London: Routledge.

Iluk, Jan. 2002. Jak uczyć małe dzieci języków obcych? Katowice: Wydawnictwo Gnome.

Jaroszewska, Anna. 2008. "Motywacja we wczesnoszkolnym nauczaniu języków obcych”. In Nowe spojrzenia na motywację w dydaktyce języków obcych, eds. Anna Michońska-Stadnik, and Zdzisław Wąsik, Vol. 2, 222-232. Wrocław: Wydawnictwo Wyższej Szkoły Filologicznej we Wrocławiu.

Kic-Drgas, Joanna. 2014. "Dzieci a nauka języków obcych”. Języki Obce w Szkole 1/2014: 92-97.

Komorowska, Hanna. 2005. Metodyka nauczania języków obcych. Warszawa: Fraszka Edukacyjna.

Kotarba-Kańczugowska, Marta. 2015. "Przedszkolak uczy się języka obcego. Kręta droga, wielka frajda". Języki Obce w Szkole 1/2015: 43-49.

Myczko, Kazimiera. 2005. "Kompetencja interkulturowa jako cel kształcenia językowego". In Dydaktyka języków obcych a kompetencja kulturowa i komunikacja interkulturowa, ed. Maciej Mackiewicz. 27-36. Poznań: Wydawnictwo Wyższej Szkoły Bankowej w Poznaniu.

Pamuła, Małgorzata. 2004. Metodyka nauczania języków obcych w kształceniu zintegrowanym. Warszawa: Fraszka Edukacyjna.

Pawłowska, Agnieszka. 2010. "Rozwijanie kompetencji interkulturowej na lekcji języka obcego". Języki Obce w Szkole 1/140: 58-66.

Reilly, Vanessa, and Sheila M Ward. (1997) 2003. Very Young Learners (Resource Books for Teachers). Reprint, Oxford: Oxford University Press.

Scott, Wendy A, and Lisbeth H Ytreberg. 1990. Teaching English to Children. New York: Longman.

Sherrill, Flora B. 2010. Cut, Color, Trace, \& Paste. Reproducible Activities for Learning and Practicing a Variety of Fine Motor Skills. Minneapolis: Key Education Publishing Company, LLC

Sobańska-Jędrych, Joanna, Beata Karpeta-Peć, and Marta Torenc. 2013. Rozwijanie zdolności językowych na lekcji języka obcego. Warszawa: Ośrodek Rozwoju Edukacji.

Sochaczewska-Kuleta, Jolanta. 2000a. "Nauczanie języka obcego przez sztukę?” Języki Obce w Szkole 6/2000: 74-76. 
Pobrane z czasopisma New Horizons in English Studies http://newhorizons.umcs.pl Data: 26/04/2023 14:31:23

Very Young Learners in a Gallery of Modern Art - Possible Opportunities Arising... 73

Sochaczewska-Kuleta, Jolanta. 2000b. "Trzy w jednym, czyli elementy plastyki, literatury dziecięcej i gry aktorskiej w nauczaniu języka obcego". Języki Obce w Szkole 6/2000: 77-80.

The New York State Education Department. Office of Bilingual Education and Foreign Languages Studies. Art as a Tool for Teachers of English Language Learners. New York: The New York State Education Department. Office of Bilingual Education and Foreign Languages Studies. 2010.

Wright, Andrew, and Safia Haleem. 1991. Visuals for the Language Classroom. New York: Longman.

Wright, Andrew. (1989) 1990. Pictures for Language Learning. Reprint, Glasgow: Cambridge University Press. 